\title{
Gambaran kadar kalsium wanita menopause di Panti Werdha Damai Manado
}

\author{
${ }^{1}$ Muchlis Syahputra \\ ${ }^{2}$ Eddy Suparman \\ ${ }^{2}$ Hermie M. M. Tendean
}

\author{
${ }^{1}$ Kandidat Skripsi Fakultas Kedokteran Universitas Sam Ratulangi Manado \\ ${ }^{2}$ Bagian Obstetri dan Ginekologi Fakultas Kedokteran Universitas Sam Ratulangi \\ RSUP Prof. Dr. R. D. Kandou Manado \\ Email: muchlissyahputra@yahoo.com
}

\begin{abstract}
One health problem that needs serious attention in the elderly is osteoporosis, characterized by decreased bone density. Calcium is the main mineral of bone-forming. This study was aimed to obtain the calcium level among menopausal women at Panti Werdha Damai (senior housing) Manado. This was an observational study with a cross sectional design. Subjects were 30 menopausal women at Panti Werdha Damai Manado from November to Desember 2015. The results showed that most subjects were $\geq 65$ years old (26 subjects; $86.67 \%$ ) BMI $\geq 23.0$ ( 15 subjects; $50 \%$ ); with clinical osteoporosis symptoms (27 subjects; $90 \%$ ). Among subjects aged $\geq 65$ years, there was 1 subjects with low calcium level; 21 with normal calcium level; and 5 with high calcium level. Among subjects aged $<65$ years, there were 2 with normal calcium level and 1 with high calcium level; none with low calcium level. Most subjets (70\%) had clinical osteoporosis symptoms. Conclusion: Most menopausal women at Panti Werdha Damai Manado had normal calcium level, however, most of them had shown clinical osteoporosis symptoms.
\end{abstract}

Keywords: calcium, menopausal women

\begin{abstract}
Abstrak: Salah satu masalah kesehatan yang perlu mendapatkan perhatian serius pada lanjut usia ialah osteoporosis yang ditandai dengan penurunan kepadatan tulang. Kalsium merupakan mineral utama pembentuk tulang. Penelitian ini bertujuan untuk mendapatkan kadar kalsium wanita menopause di Panti Werdha Damai Manado. Jenis penelitian ialah observasional dengan desain potong lintang. Subjek penelitian ialah 30 orang wanita menopause di Panti Werdha Damai Manado selama periode November-Desember 2015. Hasil penelitian memperlihatkan bahwa subjek penelitian terbanyak berusia $\geq 65$ tahun sebanyak 26 orang $(86,67 \%)$, IMT $\geq 23,0$ sebanyak 15 orang (50\%), dengan gejala klinis osteoporosis sebanyak 27 orang (90\%). Pada subjek berusia $\geq 65$ tahun terdapat 1 orang dengan kadar kalsium rendah, 21 orang dengan kadar kalsium normal, dan 5 orang dengan kadar kalsium tinggi. Pada subjek berusia $<65$ tahun terdapat 2 orang dengan kadar kalsium normal dan 1 orang dengan kadar kalsium tinggi; tidak terdapat yang mempunyai kadar kalsium rendah. Sebagian besar subjek (70\%) mempunyai gejala klinis osteoporosis. Simpulan: Sebagian besar wanita menopause di Panti Werdha Damai Manado mempunyai kadar kalsium normal. Walaupun demikian, sebagian besar telah menunjukkan gejala klinis osteoporosis.
\end{abstract}

Kata kunci: kalsium, menopause

Kekurangan kalsium dapat memicu kontraksi otot yang tidak stabil sehingga mengakibatkan kram otot. Salah satu kejadian yang sering ditemukan adalah pada wanita hamil. Selain dipicu aliran darah balik yang tidak lancar akibat 
tekanan dari rahim yang bertambah berat, kram pada wanita hamil juga dipicu oleh kekurangan kalsium. ${ }^{1}$

Di atas umur 50 tahun, jumlah kandungan kalsium dalam tubuh akan menyusut sebanyak 30\%. Kehilangan akan mencapai 50\% ketika mencapai umur 70 tahun dan selanjutnya akan mengalami masalah kekurangan kalsium. ${ }^{2}$ Menurut Perry et al. penurunan kepadatan tulang juga terjadi pada wanita pascamenopause karena indung telur mengalami penurunan produksi hormon estrogen yang akan diikuti dengan meningkatnya kalsium yang terbuang dari tubuh. ${ }^{3}$

Salah satu akibat lanjut dari osteoporosis ialah fraktur. Berdasarkan data dari WHO, angka kejadian patah tulang (fraktur) akibat osteoporosis di seluruh dunia mencapai lebih dari 8,9 juta orang setiap tahunnya, dan $17,4 \%$ kejadian ini terdapat di Asia Tenggara. ${ }^{3}$

Rendahnya kadar kalsium di Indonesia berdasarkan data dari WHO (2004) ialah 19,7\% dari jumlah lanjut usia atau sekitar 3,6 juta orang menderita osteoporosis. ${ }^{4}$ Berdasarkan survei yang dilakukan oleh Tuegeh et al. ${ }^{5}$ di Poliklinik Rematologi RSUP Prof. Dr. R. D. Kandou Manado dari data yang diperoleh dari bulan Januari sampai bulan Mei 2011 didapatkan jumlah penderita osteoporosis sebanyak 30 orang.

Berdasarkan hasil sensus penduduk tahun 2000 jumlah lanjut usia di Indonesia diproyeksikan sebesar $7,28 \%$ dan pada tahun 2020 diperkirakan sebesar 11,34\%. Pada tahun 2010, Indonesia termasuk dalam lima besar negara dengan jumlah penduduk lanjut usia terbanyak di dunia yang mencapai 18,1 juta jiwa atau 9,6\% persen dari jumlah penduduk dan diperkirakan pada tahun 2025 menjadi dua kali lipat atau sekitar 36 juta. $^{6}$

Berdasarkan uraian di atas, dapat dipahami akan pentingnya kalsium untuk lanjut usia. Hal ini ditambah dengan adanya laporan mengenai rendahnya konsumsi kalsium di Indonesia, maka peneliti tertarik untuk melakukan penelitian mengenai gambaran kadar kalsium wanita menopause di Panti Werdha Damai Manado.

\section{METODE PENELITIAN}

Jenis penelitian ini ialah deskriptif observasional dengan menggunakan rancangan potong lintang. Subjek penelitian ialah wanita menopause di Panti Werdha Damai Manado selama periode November-Desember 2015.

\section{HASIL PENELITIAN DAN BAHASAN}

Pada Tabel 1 terlihat bahwa berdasarkan usia wanita menopause di panti berusia $\geq 65$ tahun sebanyak 26 orang (86,67\%) sedangkan wanita menopause berusia $<65$ tahun terdapat 4 orang (13,33\%). Untuk IMT terdapat 5 orang (16,67\%) dengan IMT $\leq 18,5$ sedangkan IMT normal atau IMT 18,5-22,9 terdapat 10 orang $(33,33 \%)$. Pada IMT $\geq 23$ atau IMT berlebih terdapat 15 orang (50\%). Untuk gejala klinis osteoporosis, terdapat 27 orang (90\%) mengalami osteoporsis dan 3 orang (10\%) belum mengalami osteoporosis.

Tabel 1. Karakteristik wanita menopause

\begin{tabular}{lcc}
\hline Karakteristik & $\mathbf{N}$ & $\mathbf{\%}$ \\
\hline Usia & & \\
$<65$ & 4 & 13,33 \\
$\geq 65$ & 26 & 86,67 \\
Jumlah & 30 & 100 \\
\hline IMT & & \\
$<18,5$ & 5 & 16,67 \\
$18,5-22,9$ & 10 & 33,33 \\
$\geq 23,0$ & 15 & 50 \\
Jumlah & 30 & 100 \\
\hline Osteoporosis & & \\
Ada & 27 & 90 \\
Tidak ada & 3 & 10 \\
Jumlah & 30 & 100 \\
\hline
\end{tabular}

Berdasarkan usia wanita menopause pada tabel hasil penelitian terdapat 1 orang $(3,33 \%)$ pada usia $\geq 65$ tahun mengalami kekurangan kalsium. Untuk kalsium normal, pada usia $<65$ tahun terdapat 2 orang $(6,67 \%)$ dan pada usia $\geq 65$ tahun terdapat 21 orang (70\%) mempunyai kalsium normal. Untuk kadar kalsium tinggi, pada usia $<65$ tahun terdapat 1 orang $(3,33 \%)$ dan 5 orang $(16,67 \%)$ memiliki kadar kalsium tinggi. 
Tabel 2. Hasil pemeriksaan kadar kalsium

\begin{tabular}{lllllll}
\hline & \multicolumn{6}{c}{ Kadar kalsium } \\
\cline { 2 - 7 } & \multicolumn{2}{c}{ Rendah } & \multicolumn{2}{c}{ Normal } & \multicolumn{2}{l}{ Tinggi } \\
\cline { 2 - 7 } & $\mathrm{n}$ & $\%$ & $\mathrm{n}$ & $\%$ & $\mathrm{n}$ & $\%$ \\
\hline $\begin{array}{l}\text { Usia (tahun) } \\
<65\end{array}$ & - & - & 2 & 6,67 & 1 & 3,33 \\
$\geq 65$ & 1 & 3,33 & 21 & 70 & 5 & 16,67 \\
\hline IMT & 1 & 3,33 & 2 & 6,67 & 2 & 6,67 \\
$<18,5$ & - & - & 9 & 30 & 1 & 3,33 \\
$18,5-22,9$ & - & - & 12 & 40 & 3 & 10 \\
$\geq 23,0$ & - &
\end{tabular}

Gejala klinis

osteoporosis

$\begin{array}{lllllll}\text { Ada } & 1 & 3,33 & 21 & 70 & 5 & 16,67\end{array}$

\begin{tabular}{lllllll} 
Tidak ada & - & - & 2 & 6,67 & 1 & 3,33 \\
\hline
\end{tabular}

Untuk IMT $<18,5$ terdapat 1 orang (3,33\%) mengalami kekurangan kadar kalsium, 2 orang (6,67\%) mempunyai kadar kalsium normal, dan 2 orang (6,67\%) mempunyai kadar kalsium berlebih. Untuk IMT normal 18,5-22,9, terdapat 9 orang mempunyai kadar kalsium normal dan 1 orang mempunyai kadar kalsium berlebih. Untuk IMT $\geq 23$, terdapat 12 orang ( $40 \%)$ mempunyai kadar kalsium normal dan 3 orang (10\%) mempunyai kadar kalsium berlebih (Tabel 2). Pada usia tersebut IMT cenderung meningkat karena umumnya pola hidup telah berubah, pergerakan mulai dibatasi/ terbatas, jarang berolahraga, dan pola makan yang tidak teratur atau berlebih.

Tabel 2 juga memperlihatkan hasil pemeriksaan kadar kalsium darah di laboratorium klinik untuk seluruh wanita menopause (30 orang) di Panti Werdha Damai Manado pada bulan NovemberDesember 2015. Untuk kadar kalsium kurang $(<8,4 \mathrm{mg} / \mathrm{dl})$ terdapat 1 wanita menopause menderita kekurangan kalsium. Hal ini dikarenakan di atas umur 50 tahun, jumlah kandungan kalsium dalam tubuh akan menyusut sebanyak 30\%. Kehilangan akan mencapai 50\% ketika mencapai umur 70 tahun dan selanjutnya akan mengalami masalah kekurangan kalsium. ${ }^{2}$ Asupan kalsium yang tidak memadai dari makanan dan suplemen tidak menghasilkan gejala yang jelas dalam jangka pendek. Tingkat sirkulasi darah kalsium diatur secara ketat. Keadaan hipokalsemia terutama terjadi akibat masalah medis atau perawatan, termasuk gagal ginjal, operasi pengangkatan lambung, dan penggunaan obat-obatan tertentu (seperti diuretik). Gejala hipokalsemia termasuk mati rasa dan kesemutan di jari, kram otot, kejang, lesu, kurang nafsu makan, dan irama jantung abnormal. ${ }^{7}$ Jika tidak diobati, kekurangan kalsium dapat menyebabkan kematian. Pada kadar kalsium normal 8,49,7 mg/dl didapatkan 24 wanita menopause (80\%) mempunyai kadar kalsium normal. Untuk wanita menopause yang memiliki kadar kalsium berlebih (>9,7 $\mathrm{mg} / \mathrm{dl})$ terdapat 5 orang $(16,67 \%)$.

Berdasarkan gejala klinis yang didapatkan pada penelitian di panti werdha, gejala klinis osteoporosis terdapat pada 1 orang (3,33\%) dengan kadar kalsium rendah; 21 orang (70\%) dengan kadar kalsium normal; dan 5 orang $(16,67 \%)$ dengan kadar kalsium tinggi. Untuk yang tidak memiliki gejala klinis osteoporosis terdapat 2 orang $(6,67 \%)$ dengan kadar kalsium normal dan 1 orang (3,33\%) dengan kadar kalsium tinggi.

Pengeroposan massa tulang umumnya terjadi seiring bertambahnya usia. Hasil penelitian menunjukkan bahwa pada usia 25 tahun, tubuh akan mulai mengalami kekurangan kalsium sebanyak $1 \%$ per tahun. Memasuki usia 50 tahun, jumlah kalsium akan berkurang sebanyak 30\%, dan pada usia 70 tahun kehilangan kalsium akan mencapai $50 \%{ }^{2}$

Kekurangan kalsium dapat memicu kontraksi otot yang tidak stabil sehingga mengakibatkan kram otot. Pada wanita hamil hal ini sering ditemukan yang dipicu oleh aliran darah balik yang tidak lancar akibat tekanan dari rahim yang bertambah berat dan kekurangan kalsium. ${ }^{1}$

\section{SIMPULAN}

Dari hasil penelitian dapat disimpulkan bahwa sebagian besar wanita menopause di Panti Werdha Damai paling banyak mempunyai kadar kalsium normal. Walaupun demikian, sebagian besar telah 
memperlihatkan gejala klinis osteoporosis.

\section{SARAN}

1. Untuk lebih menekan angka kejadian osteoporosis pada wanita menopause diperlukan cara penanganan nutrisi dan asupan kalsium yang baik.

2. Perlu diambil langkah-langkah untuk mengurangi resiko osteoporosis pada wanita menopause antara lain dengan memperbanyak konsumsi asupan kalsium seperti susu, buah-buahan, sayur-sayuran, dan makanan-makanan lain yang mengandung kalsium tinggi

\section{DAFTAR PUSTAKA}

1. Kosnayani AS. Hubungan asupan kalsium, aktivitas fisik, paritas, indeks massa tubuh dan kepadatan tulang pada wanita pascamenopause [Tesis]. Semarang: Universitas Diponegoro; 2007.

2. Yulia C, Darningsih S. Hubungan kalsium dengan ricketsia, osteomalacia dan osteoarthritis. [cited 2014 Sep 21]. Available from: http://file.upi.edu/ Direktori/FPTK/JUR._PEND._KESE JAHTERAAN_KELUARGA/198007
012005012CICA_YULIA/HUBUNG AN_KALSIUM_DENGAN_RICKE TSIA.pdf

3. World Health Organization. WHO scientific group on the assesment of osteoporosis at primary health care level. Brussels: Summary meeting report; 2004 May 5-7; c2007

4. Karolina MS. Hubungan pengetahuan dan pencegahan osteoporosis yang dilakukan lansia di Kecamatan Medan Selayang [Skripsi]. Medan: Universitas Sumetera Utara; 2009.

5. Tuegeh J, Oeitono A, Tangka JW. Hubungan pengetahuan wanita dengan pencegahan dini osteoporosis di poliklinik rhematologi BLU RSUP Prof. Dr. R. D. Kandou Manado. Juiperdo. 2012;1(1):49-54.

6. Maryam RS, Ekasari MF, Rosidawati, Jubaedi A, Batubara I. Mengenal Usia Lanjut dan Perawatannya. Jakarta: Salemba Medika, 2008; p. 910, 31-4.

7. Butler L, Santoro N. The reproductive endocrinology of the menopausal transition. Steroids. 2011;76(7):62735. 